\title{
Microbial activity in the Greenland Sea: role of DOC lability, mineral nutrients and temperature
}

\author{
Mathias Middelboe $^{1, *}$, Claus Lundsgaard ${ }^{2}$
}

\author{
${ }^{1}$ Marine Biological Laboratory, University of Copenhagen, Strandpromenaden 5, 3000 Helsingør, Denmark \\ ${ }^{2}$ National Environmental Research Institute, Frederiksborgvej 399, 4000 Roskilde, Denmark
}

\begin{abstract}
Bacterial turnover of dissolved organic carbon (DOC) and the regulation of bacterial activity was investigated during 2 cruises in the Greenland Sea in June and August 1999, in order to provide information on the role of bacteria for the biogeochemical cycling of DOC in the northern North Atlantic. We measured the actual pool size of labile DOC (DOC-L) and in situ bacterial growth rate (production:biomass ratio; $\mathrm{P}: \mathrm{B}$ ) in vertical profiles in the Greenland Sea, covering a depth range from surface to $3662 \mathrm{~m}$ depth. In situ bacterial growth rates ranged from 0.0002 to $0.5 \mathrm{~d}^{-1}$, and significant bacterial growth was observed down to the deepest samples. Approximately half of the variation in in situ growth rate could be described by a model with DOC-L $(\mu \mathrm{M})$ and temperature $\left({ }^{\circ} \mathrm{C}\right)$ as variables: $\log (\mathrm{P}: \mathrm{B})=0.37 \times \log (\mathrm{DOC}-\mathrm{L})+0.059 \times$ temperature $-2.41\left(\mathrm{r}^{2}=0.47, \mathrm{p}<0.0001\right) . \mathrm{DOC}-\mathrm{L}$ concentration ranged from 13.5 $\mu \mathrm{M}$ (surface waters) to $<0.1 \mu \mathrm{M}$ in some of the deep-water samples and showed a significant decrease with depth. The presence of DOC-L in samples from below $1000 \mathrm{~m}$ depth (average $0.28 \pm 0.21 \mu \mathrm{M} \mathrm{C}(\mathrm{n}=12)$ ) suggested an efficient transport of organic carbon from the productive layer, possibly by sedimenting particles. Growth experiments with bacterioplankton from surface waters and deep waters of the Greenland Sea showed significant influence of both temperature $\left({ }^{\circ} \mathrm{C}\right)$ and DOC-L $(\mu \mathrm{M})$ on bacterial growth rate $\left(\mu_{;} \mathrm{d}^{-1}\right)$ as described by $\log (\mu)=0.25 \times$ $\log ($ DOC-L $)+0.081 \times$ temperature $-1.14\left(r^{2}=0.73, p<0.0001\right)$. Inorganic nutrient concentration did not affect bacterial growth rate. Our findings suggest that bacterial DOC uptake in the Greenland Sea is controlled by a combination of temperature and the concentration of DOC-L.
\end{abstract}

KEY WORDS: Bacteria - Dissolved organic carbon - Substrate - Temperature · Greenland Sea · $Q_{10}$-factor

\section{INTRODUCTION}

Dissolved organic carbon (DOC) accumulates during spring and summer in the surface waters of the Greenland and Norwegian Seas (Børsheim \& Myklestad 1997, Børsheim 2000, Lundsgaard et al. unpubl. data), thus, the rate of DOC decomposition is lower than DOC production during that period. Accumulation of DOC in marine surface waters may be due to limitation of bacterial activity by temperature or nutrient availability or it may simply be because the produced DOC is only slowly degradable or refractory to bacterial degradation. The DOC that accumulates in the Greenland and Norwegian Seas during spring and summer is, however, lost from the surface water during the autumn and winter months (Børsheim \& Myklestad 1997, Lundsgaard et al. unpubl. data). Part of the DOC removal may be due to microbial mineralization and part may be the result of translocation of the DOC by mixing or convection processes and horizontal transport (Noji et al. 1999b, Børsheim 2000, Buch et al. 2001). The relative importance of these mechanisms for the removal of DOC from the Greenland Sea surface waters is not fully known; however, bacterial carbon demand in summer suggests that accumulated pools may be mineralized within months in the upper layer (Børsheim 2000).

In general, the largest part ( $>60 \%$ ) of the bulk DOC pool is refractory to bacterial degradation (i.e. turnover times of decades or more). The biodegradable fraction 
of the DOC consists of carbon components with turnover times that range from hours to years; however, the labile DOC (DOC-L) has operationally been defined as the amount of DOC that can be utilized by bacteria within 1 to $2 \mathrm{wk}$ of incubation (Søndergaard \& Middelboe 1995).

The concentration of DOC-L is influenced by a number of factors, which affect bacterial DOC utilization. The affinity towards the given DOC-L of the dominant bacterial populations will influence the rate of DOC uptake, and low affinity to a given DOC-L pool of the bacterial community may lead to accumulation of DOC-L (Søndergaard \& Middelboe 1995). Limitation of bacterial growth by the availability of inorganic nutrients or predation have been proposed as alternative mechanisms for accumulation of DOC-L (Thingstad et al. 1997, 1998), since grazer control or inorganic nutrient limitation of bacterioplankton may cause periodic reduction of bacterial carbon uptake. Finally, temperature may be an important factor controlling bacterial carbon uptake. Heterotrophic bacteria can physiologically adapt to low temperatures, and have proven to be important components of the pelagic microbial food web at high latitudes (e.g. Wheeler et al. 1996, Middelboe et al. 2002). The psychrophilic and psychrotolerant bacteria in Arctic pelagic systems, however, usually operate far below their optimal temperature, and the temperature regulation has been shown to interact with substrate limitation leading to a more pronounced reduction in bacterial activity with decreasing temperature at low than at high substrate concentrations (Pomeroy \& Wiebe 2001).

The vertical flux of DOC out of the euphotic zone is mainly mediated by turbulent mixing and convection (Rudels \& Quadfasel 1991) and by dissolution of sinking particles (Cho \& Azam 1988, Smith et al. 1992). Areas with deep-water convection like the northern North Atlantic are important for the global carbon cycling, and they have a great potential for export of DOC from the surface waters to the deep sea. In order to increase our understanding of the role of vertical transport and mineralization in the turnover of accumulated DOC in the surface water, it is essential to study the rate of bacterial DOC mineralization and the regulation of this process in the upper mixed layers and in the deep ocean.

The aim of the present study was to investigate the mechanisms that control bacterial DOC decomposition in order to provide information on the role of bacteria in the biogeochemical cycling of DOC in the Greenland Sea and the export of organic carbon to the deep ocean. We examined the influence of DOC-L concentration, temperature and concentration of inorganic nutrients as factors controlling bacterial DOC decomposition in manipulated batch cultures with bacterio- plankton from surface waters and deep waters of the Greenland Sea. In addition, we measured the actual pool size of DOC-L, and the bacterial biomass and carbon demand in vertical profiles in the Greenland Sea, covering a depth range from surface to $3662 \mathrm{~m}$ depth. Other aspects of the microbial carbon cycling and DOC dynamics on a temporal and spatial scale in the Greenland Sea and the North Atlantic deep-water are treated elsewhere (Bendtsen et al. 2002, Lundsgaard et al. unpubl. data).

\section{MATERIALS AND METHODS}

Bacterial growth experiments. Bacterial abundance was measured daily in batch culture experiments with natural bacterial assemblages. Parallel measurements of particulate organic carbon and oxygen consumption at selected time points allowed calculation of bacterial cell carbon content and growth efficiency, which was used to estimate biomass and DOC uptake from the growth in bacterial abundance.

Water samples for bacterial growth experiments were collected during 2 cruises on RV 'Dana' in the Greenland Sea, from June 2 to 20 and August 3 to 22, 1999. Experiments were conducted on board during the cruises. At 4 stations, samples were taken for bacterial growth experiments (Table 1). In 3 of the experiments water from the upper $40 \mathrm{~m}$ was used, and in 1 experiment we used bottom water (2700 m depth). All bottles for sampling, filtration and incubation, as well as the filtration units, were cleaned, first with $4 \%$ hydrochloride acid, then Milli-Q water and finally sample water. A 40 to $50 \mathrm{l}$ water sample was filtered through $0.2 \mu \mathrm{m}$ filters (Whatman Polycap 36AS) into polycarbonate carboys. A bacterial inoculum was prepared from the same natural water sample by filtration through a $0.6 \mu \mathrm{m}$ Nucleopore polycarbonate filter. The inoculum was mixed with the $0.2 \mu \mathrm{m}$ filtrate in a 1:10 ratio. The diluted bacteria were then distributed into a series of 21 polycarbonate or glass bottles, which were then manipulated with respect to incubation temperature, and concentration of DOC- $\mathrm{L}_{1} \mathrm{PO}_{4}{ }^{3-}$ and $\mathrm{NH}_{4}{ }^{+}$ (Table 1). A series of $60 \mathrm{ml}$ BOD bottles (12 bottles for each manipulation) were incubated in parallel to measure bacterial respiration. All cultures were incubated for 11 to $12 \mathrm{~d}$ in darkness in a thermostatic cold room or in thermos baths. Mixing was achieved by inverting the bottles by hand several times per day.

Subsamples for determination of bacterial abundance were fixed in glutaraldehyde $(1.25 \%$ final concentration). Bacteria were counted by flow cytometry on a FACS Calibur flow cytometer (Becton Dickinson) after staining of the fixed cells with the nucleic acid stain SYBR Green 1 (Molecular Probes) according to 
Table 1. Experimental setup of the manipulated batch cultures indicating added concentrations of glucose and inorganic nutrients as well as incubation temperatures in the 4 growth experiments. SCM: subsurface chlorophyll maximum. In situ nutrient conc.: concentration of inorganic $\mathrm{N}$ and $\mathrm{P}$ in the original water samples

\begin{tabular}{|c|c|c|c|c|c|c|c|c|}
\hline $\begin{array}{l}\text { Water } \\
\text { sample }\end{array}$ & $\begin{array}{c}\text { In situ } \\
\text { nutrient conc. }\end{array}$ & Control & $+\mathrm{C}$ & $+\mathrm{N}$ & $+\mathrm{P}$ & + Temp. & $\begin{array}{l}+\mathrm{C}_{1} \mathrm{~N}_{1} \mathrm{P}_{i} \\
+ \text { Temp. }\end{array}$ & - Temp. \\
\hline $\begin{array}{l}\text { Expt } 1 \\
73.28^{\circ} \mathrm{N}, 01.00^{\prime} \mathrm{E} \\
7 \text { June } 1999 \\
40 \text { m depth (SCM) }\end{array}$ & $\begin{array}{l}7.1 \mu \mathrm{M} \mathrm{N} \\
0.44 \mu \mathrm{M} \mathrm{P}\end{array}$ & $2^{\circ} \mathrm{C}$ & $\begin{array}{c}5 \mu \mathrm{M} \text { glucose } \\
2^{\circ} \mathrm{C}\end{array}$ & $\begin{array}{c}10 \mu \mathrm{M} \mathrm{NH}_{4}^{+} \\
2^{\circ} \mathrm{C}\end{array}$ & $\begin{array}{c}5 \mu \mathrm{M} \mathrm{PO}_{4}^{-} \\
2^{\circ} \mathrm{C}\end{array}$ & $7^{\circ} \mathrm{C}$ & - & - \\
\hline $\begin{array}{l}\text { Expt } 2 \\
75.00^{\circ} \mathrm{N}, 10.25^{\prime} \mathrm{W} \\
8 \text { June } 1999 \\
17 \text { m depth (SCM) }\end{array}$ & $\begin{array}{r}2.7 \mu \mathrm{M} \mathrm{N} \\
0.54 \mu \mathrm{M} \mathrm{P}\end{array}$ & $2^{\circ} \mathrm{C}$ & $\begin{array}{c}5 \mu \mathrm{M} \text { glucose } \\
2^{\circ} \mathrm{C}\end{array}$ & $\begin{array}{c}10 \mathrm{\mu M} \mathrm{NH}_{4}^{+} \\
2^{\circ} \mathrm{C}\end{array}$ & $\begin{array}{c}5 \mathrm{\mu M} \mathrm{PO}_{4}^{-} \\
2^{\circ} \mathrm{C}\end{array}$ & $7^{\circ} \mathrm{C}$ & - & - \\
\hline $\begin{array}{l}\text { Expt 3 } \\
74.32^{\circ} \mathrm{N}, 07.50^{\prime} \mathrm{W} \\
8 \text { August } 1999 \\
5 \text { m depth }\end{array}$ & $\begin{array}{l}<0.1 \mu \mathrm{M} \mathrm{N} \\
0.08 \mu \mathrm{M} \mathrm{P}\end{array}$ & $3^{\circ} \mathrm{C}$ & $\begin{array}{c}5 \mu \mathrm{M} \text { glucose } \\
3^{\circ} \mathrm{C}\end{array}$ & $\begin{array}{c}10 \mu \mathrm{M} \mathrm{NH}_{4}^{+} \\
3^{\circ} \mathrm{C}\end{array}$ & $\begin{array}{c}5 \mu \mathrm{M} \mathrm{PO}_{4}^{-} \\
3^{\circ} \mathrm{C}\end{array}$ & $8^{\circ} \mathrm{C}$ & $\begin{array}{c}5 \mu \mathrm{M} \text { glucose, } \\
10 \mu \mathrm{M} \mathrm{NH}_{4}{ }^{+} \\
5 \mu \mathrm{M} \mathrm{PO}_{4}^{-}{ }^{;} \\
8^{\circ} \mathrm{C}\end{array}$ & $-1^{\circ} \mathrm{C}$ \\
\hline $\begin{array}{l}\text { Expt } 4 \\
74.45^{\circ} \mathrm{N}, 09.40^{\prime} \mathrm{W} \\
9 \text { August } 1999 \\
2700 \mathrm{~m} \text { depth }\end{array}$ & $\begin{array}{l}10.3 \mu \mathrm{M} \mathrm{N} \\
0.90 \mu \mathrm{M} \mathrm{P}\end{array}$ & $-1^{\circ} \mathrm{C}$ & $\begin{array}{c}5 \mu \mathrm{M} \text { glucose } \\
-1^{\circ} \mathrm{C}\end{array}$ & $\begin{array}{c}10 \mathrm{MM} \mathrm{NH}_{4}{ }^{+} \\
-1^{\circ} \mathrm{C}\end{array}$ & $\begin{array}{c}5 \mu \mathrm{M} \mathrm{PO}_{4}^{-} \\
-1^{\circ} \mathrm{C}\end{array}$ & $3^{\circ} \mathrm{C}$ & $\begin{array}{c}5 \mu \mathrm{M} \text { glucose } \\
10 \mu \mathrm{M} \mathrm{NH}_{4}^{+}, \\
5 \mu \mathrm{M} \mathrm{PO}_{4}^{-} ; \\
3^{\circ} \mathrm{C}\end{array}$ & - \\
\hline
\end{tabular}

Marie et al. (1997). Briefly, the $1 \mathrm{ml}$ samples received additions of $10 \mu \mathrm{l}$ of a $100 \times$ dilution of stock SYBR Green 1 and $10 \mu \mathrm{l}$ of a suspension of $2 \mu \mathrm{m}$ fluorescent beads (Polyscience). The concentration of the beads, which was used for volume calibration, was determined by epifluorescence microscopy after filtration onto $0.2 \mu \mathrm{m}$ filters. Bacterial growth rate was measured from the increase in cell abundance during exponential growth in the cultures (the slope of the regression line of $\ln$ [abundance] vs time). For the detection of potential flagellate contamination, glutaraldehyde fixed samples (15 to $50 \mathrm{ml}$ ) from the end of each incubation were stained with DAPI and filtered onto black $0.8 \mu \mathrm{m}$ pore size polycarbonate filters, which were inspected using epifluorescence microscopy (Porter \& Feig 1980). The fraction of filters analyzed corresponded to a detection limit of 2 to 5 flagellates $\mathrm{ml}^{-1}$. No flagellates were found in the growth experiments.

Subsamples for particulate organic carbon (POC) were taken on Days 0, 3, 7 and 11, and 100 to $200 \mathrm{ml}$ of subsample was filtered onto $13 \mathrm{~mm}$ GF/F filters (precombusted $450^{\circ} \mathrm{C}, 2 \mathrm{~h}$ ), which were then stored frozen. For analysis of POC, the filters were acidified to remove inorganic carbon, dried $\left(60^{\circ} \mathrm{C}, 2 \mathrm{~h}\right)$ and subsequently combusted at $650^{\circ} \mathrm{C}$ in a tube furnace (Carbolite MTE 10/25) flushed with $\mathrm{O}_{2}$ at a flow rate of $400 \mathrm{ml}$ $\mathrm{min}^{-1}$ (Søndergaard \& Middelboe 1993). The $\mathrm{CO}_{2}$ was measured with an infrared gas analyzer (ADC 225 MK3) connected to a signal integrator. POC measurements were calibrated with standards made from glucose solutions added in small volumes (3 to $10 \mu \mathrm{l}$ ) to precombusted GF/F filters and dried. Blank filters were prepared by filtration of 5 to $50 \mathrm{ml} 0.2 \mu \mathrm{m}$ filtered sample through $13 \mathrm{~mm} \mathrm{GF/F}$ filters to correct for DOC retained in the filters after filtration (Søndergaard \& Middelboe 1993). The measurements of POC were less sensitive and precise, and were taken less frequently than the cell counting. Therefore, concurrent measurements of POC and bacterial abundance were used to estimate mean values of cell carbon content, and these conversion factors were then used to convert the large data set of bacterial abundance to biomass values. Cell abundance was too low in Expt 4 to give significant POC data, thus cell carbon content from Expt 3 was applied for biomass calculations.

For $\mathrm{O}_{2}$ consumption measurements, triplicate BOD bottles were harvested on Days 0, 3, 7 and 11 and $\mathrm{O}_{2}$ was measured by Winkler titration using an automated titrator (716 DMS Titrino, Metrohm). $\mathrm{O}_{2}$ consumption was converted to carbon respiration using a respiratory quotient of 0.85 . The combined measurements of respiration and biomass increase in Expts 1, 2 and 3 were used to estimate bacterial growth efficiency during the exponential growth phase in the cultures. However, samples where temperature was increased relative to in situ values were not included, since the temperature-dependent changes in saturation level may have caused bubble formation and erroneous respiration estimates. In Expt 4, the $\mathrm{O}_{2}$ consumption was too low to allow a calculation of a significant bacterial growth yield based on Winkler technique. Data from cultures with similar growth efficiency were grouped and aver- 
age growth efficiencies were calculated for conversion of growth in terms of biomass to corresponding values of DOC uptake. Data from Expt 4 were converted using same growth efficiencies as in Expt 3.

DOC lability. The concentration of DOC-L was measured as the amount of carbon that was utilized by the natural bacterial assemblage, when allowed to grow to reach the carrying capacity with respect to organic carbon sources in the sample (Søndergaard \& Middelboe 1995). During the incubations, samples were collected for bacterial abundance and POC (as above), and the concentration of DOC-L was calculated as the carbon uptake required to obtain the net increase in bacterial biomass applying the growth efficiency determined in the growth experiments (Expts 1 to 3 ).

Water samples for measurements of DOC-L were collected at 8 stations during the August cruise in the Greenland Sea (positions: $72.55^{\circ} \mathrm{N}, 05.00^{\circ} \mathrm{E}_{\text {; }} 73.38^{\circ} \mathrm{N}$, $00.30^{\circ} \mathrm{W}_{;} 74.32^{\circ} \mathrm{N}, 07.50^{\circ} \mathrm{W} ; 75.00^{\circ} \mathrm{N}, 12.00^{\circ} \mathrm{W}_{i} 75.00^{\circ} \mathrm{N}$, $07.01^{\circ} \mathrm{W} ; \quad 75.00^{\circ} \mathrm{N}, 07.01^{\circ} \mathrm{E} ; \quad 75.32^{\circ} \mathrm{N}, 05.20^{\circ} \mathrm{E} ;$ and $77.30^{\circ} \mathrm{N}, 3.20^{\circ} \mathrm{W}$ ). At each station, water was sampled from 7 to 8 different depths and the whole sampling program covered a depth range of 5 to $3662 \mathrm{~m}$. A 1 to 21 water sample from each depth was GF/C-filtered (Whatman; precombusted at $450^{\circ} \mathrm{C}$ for $2 \mathrm{~h}$ and rinsed with sample water before collection of filtrate) and $10 \mu \mathrm{M} \mathrm{NH}_{4}{ }^{+}$and $5 \mu \mathrm{M} \mathrm{PO}_{4}{ }^{3-}$ were added to ensure that bacterial growth during incubation was controlled by organic carbon and not inorganic nutrients. The filtrate was transferred into triplicate $300 \mathrm{ml}$ glass bottles, which had been acid cleaned and rinsed with Milli-Q water and sample water before use. This procedure had been tested to ensure the same effect as a precombustion at $550^{\circ} \mathrm{C}$ for $2 \mathrm{~h}$ (data not shown), thereby removing any organic material contained in the bottles prior to use. Bottles were incubated for $7 \mathrm{~d}$ at $20^{\circ} \mathrm{C}$ and mixing was achieved by means of daily manual inversions.

From each water sample, subsamples for bacterial abundance measurements were taken daily from one of the triplicate bottles and fixed in glutaraldehyde ( $1.25 \%$ final conc.). From the other 2 bottles, subsamples were only taken initially and after $7 \mathrm{~d}$ and analyzed for bacterial abundance and POC concentration as well as for presence of bacterivorous protozoa. The same analysis methods described for growth experiments were used. Flagellate growth was detected in some of the surface water samples and these were therefore not used for estimating DOC-L concentrations. POC measurements were less sensitive and precise than cell counting, and significant POC increases were only detected in incubations with a large increase in bacterial abundance. We chose to use an average value of cell carbon content from these incubations with sufficient growth for calculating biomass from abundance in all incubations.
In situ measurements. During both cruises, the vertical and horizontal distributions of bacterial abundance and production were monitored along 4 transects in the Greenland Sea, within an investigation area extending from $07.00^{\circ} \mathrm{E}$ to $12.00^{\circ} \mathrm{W}$ and from 72.55 to $77.30^{\circ} \mathrm{N}$. Bacterial abundance was measured by flow cytometry after staining with SYBR-Green 1 (Molecular Probes) and converted to biomass using the conversion factors determined in the growth experiments $(2.4$ and $1.9 \mathrm{fmol} \mathrm{C}$ cell $^{-1}$ for the June and August cruises, respectively). Bacterial production was estimated from incorporation of ${ }^{3} \mathrm{H}$-thymidine and ${ }^{14} \mathrm{C}$-leucine (ChinLeo \& Kirchman 1988), however, only the leucine data set has been presented here because leucine uptake showed higher sensitivity than thymidine at the very low uptake rates. Conversion was based on empirically determined factors of 172 and $107 \mathrm{~mol} \mathrm{C} \mathrm{(mol}$ leucine $)^{-1}$ for the June and August data, respectively (Lundsgaard et al. unpubl. data). From the measurements of bacterial abundance and production, in situ bacterial growth rate was estimated as production divided by the biomass $(\mathrm{P}: \mathrm{B})$.

Concentrations of inorganic nutrients in the original water samples used for growth experiments were analyzed according to Grasshoff et al. (1983).

\section{RESULTS}

\section{Bacterial growth experiments}

From the June and August experiments, respectively, cell carbon contents of $2.4 \pm 0.4$ and $1.9 \pm 0.1$ fmol C cell ${ }^{-1}( \pm 1 \mathrm{SE})$ were obtained (Fig. 1 ; only data from August are presented). Growth efficiencies varied in relation to glucose enrichment in a consistent way in Expts 1 to 3, i.e. the efficiency was $0.26 \pm 0.01$ without glucose addition and $0.36 \pm 0.02( \pm 1 \mathrm{SE})$ in carbon enriched cultures (Fig. 2). Other differences in growth efficiency related to experiment and treatment were not systematic or significant.

Bacterial growth in the control cultures represented the potential of the natural bacterial assemblage to grow on the available DOC pool at in situ temperature. Three different phases could be detected in some of the growth experiments: an initial lag phase, an exponential growth phase and a final phase with reduced or no growth. A clear identification of the point of transition from lag to exponential growth phase was difficult to make, because of low relative counting precision at low cell numbers, and because transition may have been gradual in the mixed assemblage. Potentially, the lag phase seemed to last for 0 to $5 \mathrm{~d}$, but the length of this phase seemed not to correlate with experiment or treatment. The end of the exponential growth phase 


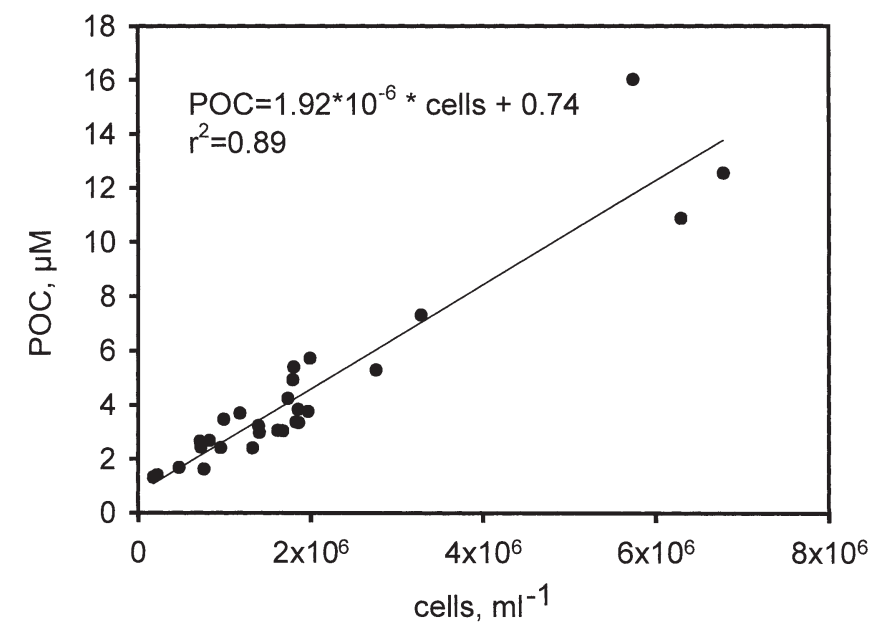

Fig. 1. Regression between POC and bacterial cell abundance in one of the growth experiments (Expt 3). Data are from Days 3, 7 and 11 and include all manipulations

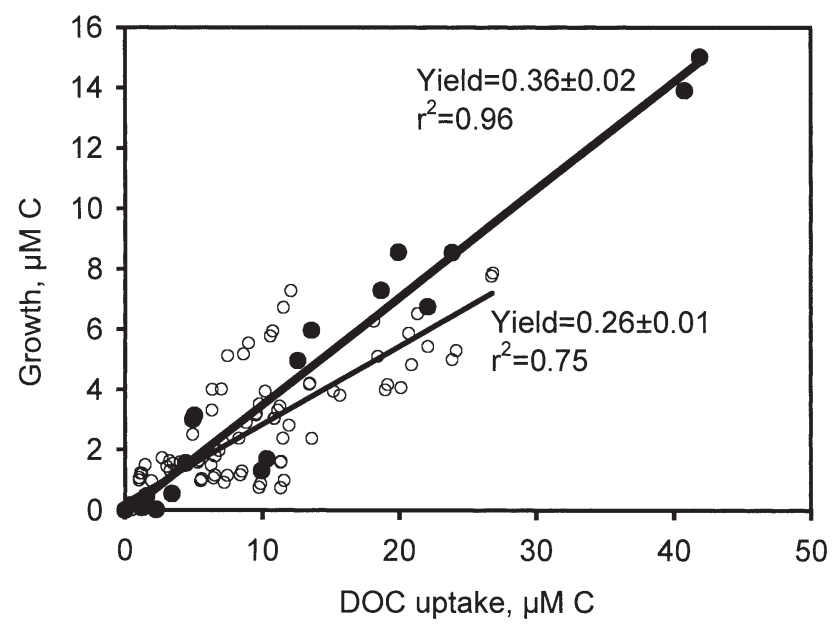

Fig. 2. Regression between bacterial growth (increase in biomass) and DOC uptake (oxygen consumption + increase in biomass) from Expts 1 to 3. (0) Data from cultures without glucose addition; $(\bullet)$ data from cultures with glucose addition. Data are from Days 0, 3, 7 and 11 of the incubations. Results from cultures with temperature manipulation are not included. Slope of the regression line $( \pm \mathrm{SE})$ represents growth efficiency (yield)

was easier to determine from inflection points on plots of $\ln$ (abundance) versus time, however, only in some of the experiments was this point reached within $11 \mathrm{~d}$. Calculation of growth rate was based on linear regression analysis of $\ln$ (abundance) versus time for the period from the start of the experiment to the end of the exponential growth phase, ranging from Day 5 to termination of the experiment (Day 11). Inclusion of the actual lag phase gave more consistent growth rates than if the estimated lag phase was excluded. When a secondary growth phase following the first exponential growth phase was reached, the growth rate ranged from 0 to $60 \%$ (average $20 \%$; data not shown) of the rate in the first exponential phase (including the lag phase).

The effects of the different treatments on the temporal development of the bacterial biomass were essentially the same at the 3 surface water experiments, and therefore we have only presented these data for $1 \mathrm{ex}$ periment (Expt 3), which included all the different types of treatments used (Fig. 3). The total bacterial DOC uptake and the bacterial growth rates during the incubations are, however, presented for all the experiments (Table 2, Figs. 4 \& 5). Addition of inorganic nutrients had no significant effects on bacterial growth rate and carbon uptake in the cultures. Bacterial carbon uptake at in situ temperature and without carbon addition ranged from 9.9 to $21.8 \mu \mathrm{M} \mathrm{C}$ in the surface water experiments (Expts 1 to 3), and from 0.5 to $0.9 \mu \mathrm{M} \mathrm{C}$ in the
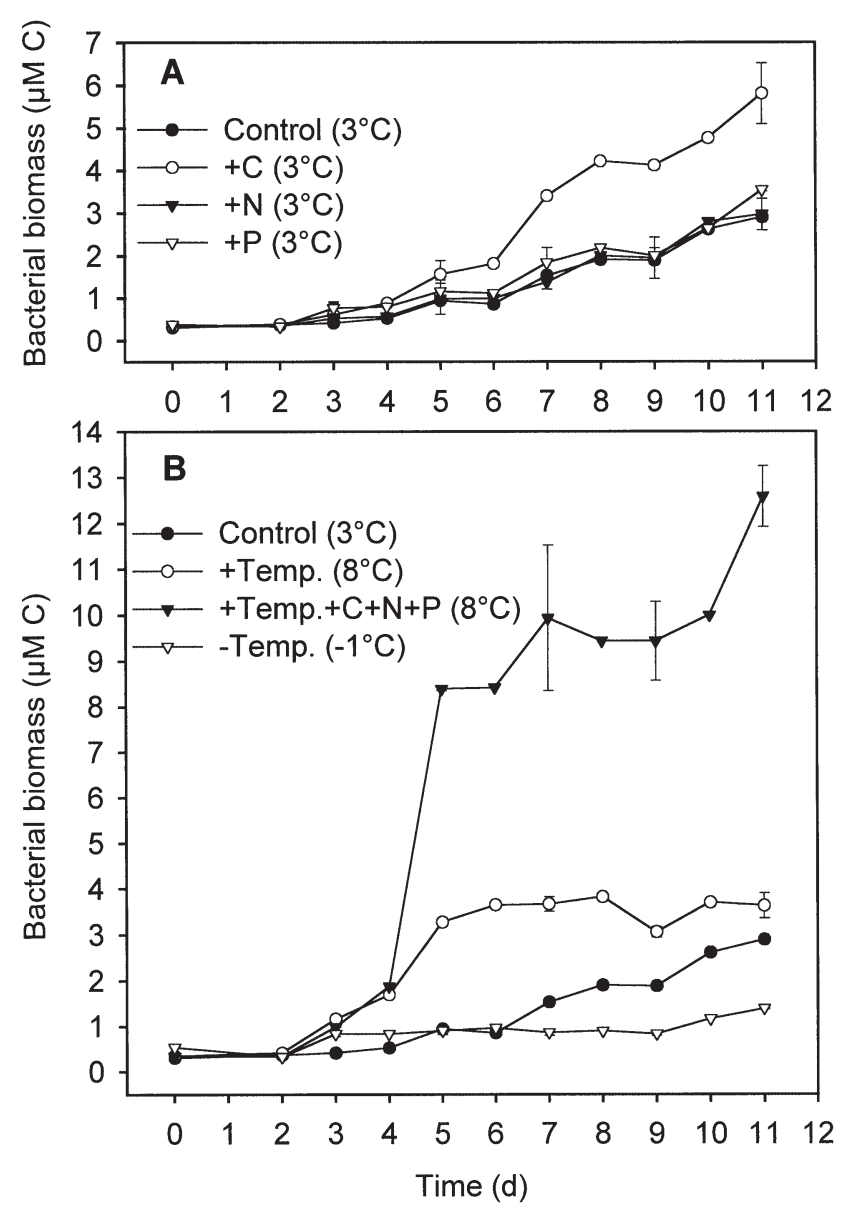

Fig. 3. Development in bacterial biomass in one of the bacterial growth experiments (Expt 3). Different lines represent results from duplicate cultures manipulated with respect to (A) addition of organic carbon, inorganic nutrients and (B) incubation temperature. Error bars = standard deviation 
Table 2. Bacterial DOC uptake ( $\mu \mathrm{M}$ C) during $11 \mathrm{~d}$ incubation in the 4 growth experiments

\begin{tabular}{|c|c|c|c|c|c|c|c|}
\hline & Control & $+\mathrm{C}$ & $+\mathrm{N}$ & $+\mathrm{P}$ & + Temp. & $+\mathrm{C}_{1} \mathrm{~N}_{1} \mathrm{P}_{i}+$ Temp. & - Temp. \\
\hline Expt 1 & $12.2 \pm 0.8$ & $22.0 \pm 2.5$ & $14.1 \pm 1.9$ & $14.3 \pm 1.2$ & $14.0 \pm 5.2$ & - & - \\
\hline Expt 2 & $21.8 \pm 0.6$ & $40.2 \pm 2.2$ & $17.1 \pm 2.1$ & $15.7 \pm 0.5$ & $48.6 \pm 9.3$ & - & - \\
\hline Expt 3 & $9.9 \pm 1.2$ & $15.2 \pm 2.0$ & $10.2 \pm 1.4$ & $12.2 \pm 0.2$ & $12.6 \pm 1.1$ & $34.0 \pm 1.8$ & $3.3 \pm 0.05$ \\
\hline Expt 4 & $0.84 \pm 0.14$ & $0.58 \pm 0.02$ & $0.85 \pm 0.15$ & $0.49 \pm 0.03$ & $1.0 \pm 0.3$ & $2.0 \pm 0.1$ & - \\
\hline
\end{tabular}

deep-water experiment (Expt 4; $2700 \mathrm{~m},-1^{\circ} \mathrm{C}$ ) (Table 2). Bacterial growth rates in the control and $\mathrm{N}$ and P-enriched cultures ranged from 0.20 to $0.38 \mathrm{~d}^{-1}$ in the surface water experiments, and from 0.04 to $0.07 \mathrm{~d}^{-1}$ in the deep-water experiment. Bacterial carbon uptake and growth rate was significantly $(p<0.05)$ higher in Expt 2, with surface water taken closer to the ice-edge than in Expts 1 and 3, where water from the central Greenland Sea was used (Figs. 4 \& 5, Table 2).

Addition of $5 \mu \mathrm{M}$ glucose $(30 \mu \mathrm{M}$ C) increased the bacterial carbon uptake in all the surface water experiments (Table 2). The carbon uptake indicated that the added glucose plus the natural pool of DOC-L
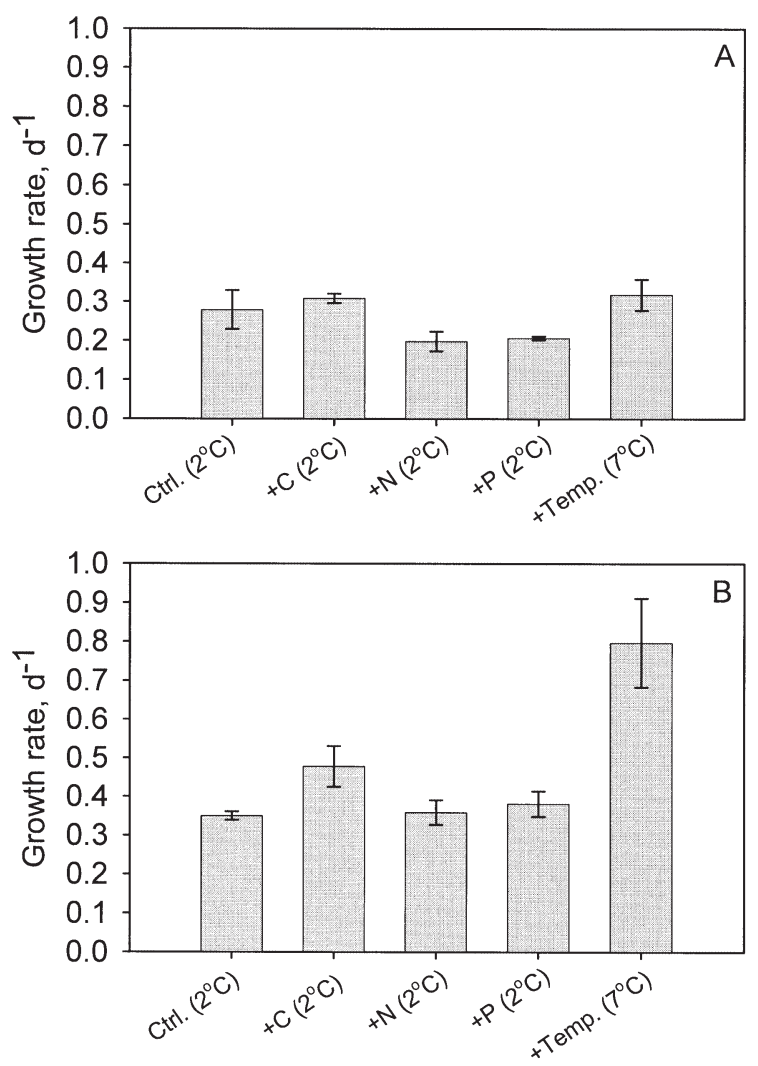

Fig. 4. Bacterial growth rate in the different treatments in bacterial growth experiments performed during the June cruise. (A) Expt 1 with surface water from chlorophyll maximum $(40 \mathrm{~m})$. (B) Expt 2 with water from chlorophyll maximum $(17 \mathrm{~m})$. Data represent the average and standard deviation from duplicate treatments (=uptake in the control culture) was not utilized completely within $11 \mathrm{~d}$ at in situ temperature. Only in Expt 2 did the carbon uptake account for more than the added glucose. In Expts 1 and 2, the bacterial biomass was still increasing when the incubations were terminated; thus both the added glucose and the natural DOC-L may have been taken up given a longer incubation period. In Expt 3, the utilization of added glucose may have been limited by nitrogen, since concentration of $\mathrm{NO}_{3}$ was $<0.05 \mu \mathrm{M}$ in this water sample, while concentrations were $>2 \mu \mathrm{M}$ in the other experiments (Table 1). The concentration of ammonia was not known in the water from Expt 3, but concentrations
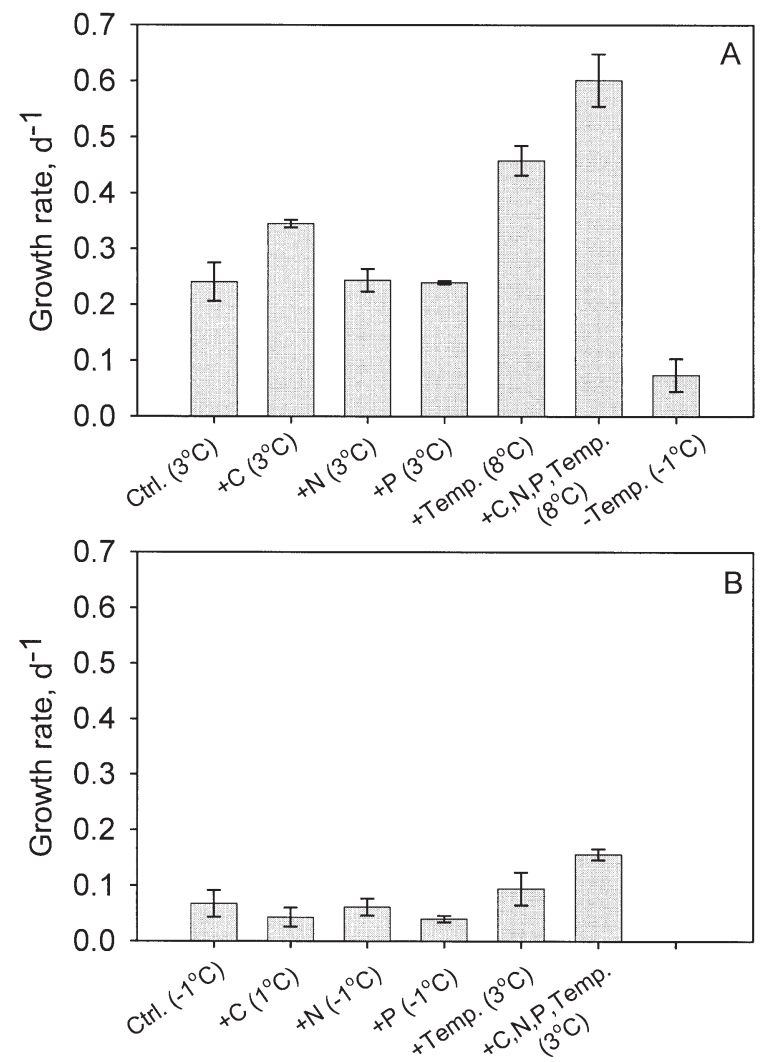

Fig. 5. Bacterial growth rate in the different treatments in bacterial growth experiments performed during the August cruise. (A) Expt 3 with surface water (5 m). (B) Expt 4 with deep water $(2700 \mathrm{~m})$. Data represent the average and standard deviation from duplicate treatments 
were $<0.05 \mu \mathrm{M}$ in the surface water at other stations on the August cruise. Bacterial growth rate was also significantly affected by the addition of DOC-L in Expts 1 to 3 and the rate increased by 27 to $37 \%$ relative to control cultures $(p<0.05)$. In the deep-water experiment (Expt 4), on the other hand, the bacterial assemblage was not able to utilize the added glucose within the incubation period at the given temperature, since the addition of DOC-L alone did not influence bacterial carbon uptake or growth rate (Fig. 5, Table 2).

Increasing the incubation temperature by $5^{\circ} \mathrm{C}$ also had a significant positive effect on bacterial growth rate in the surface water experiments ( $p<0.05$, Figs. 4 \& 5). In Expt 1 and 3, bacteria used up the DOC-L during the $11 \mathrm{~d}$ incubations in the control cultures, and the increased incubation temperature only increased the rate at which bacteria reached the stationary phase (Fig. 3, Table 2). In Expt 2, on the other hand, the increased incubation temperature allowed a larger fraction of DOC$\mathrm{L}$ to be taken up by bacteria within the $11 \mathrm{~d}$ incubation (Table 2). In Expt 4, an increased incubation temperature alone increased bacterial growth rate from $0.068 \mathrm{~d}^{-1}$ to $0.094 \mathrm{~d}^{-1}$, although not significantly, while the temperature increase did not affect the total carbon uptake (Fig. 5, Table 2). Thus, at the low temperature $\left(-1^{\circ} \mathrm{C}\right)$ and DOC-L concentration $(\sim 0.8 \mu \mathrm{M} \mathrm{C})$ in the deep-water experiment, the bacterial growth rate was lower than in the surface water and was not stimulated by DOC-L addition alone. However, combining the addition of DOC-L with incubation at higher temperature in Expts 3 and 4 increased bacterial carbon uptake and growth rate significantly, relative to both the control cultures and cultures only with added glucose $(p<0.01)$.

Reducing the incubation temperature from +3 to $-1{ }^{\circ} \mathrm{C}$ in Expt 3 significantly reduced bacterial growth rate to $0.07 \pm 0.03 \mathrm{~d}^{-1}$ ( $<<0.01$; Fig. 5) and the stationary phase was not reached within the incubation period. Consequently, the carbon uptake was reduced to $30 \%$ of the uptake in the controls ( $p<0.01$; Fig. 3 , Table 2). The effect of temperature manipulation in cultures with different origin and DOC-L concentration is summarized in Fig. 6. The slopes of the lines indicate that the average $Q_{10}$ value was higher in the lower temperature range than in the upper. However, due to the variability and the limited number of temperatures tested, these data do not allow a more precise description of the growth rate-temperature relationship.

The combined effect of DOC-L and temperature on bacterial growth rate in the growth experiments was analyzed using multiple linear regression and ANOVA (Table 3). $73 \%$ of the variance was explained by the model: $\log (\mu)=0.081 \times$ temperature $+0.249 \times$ $\log ($ DOC-L $)-1.139$. Both the overall model and the influence of the 2 independent variables were signifi-

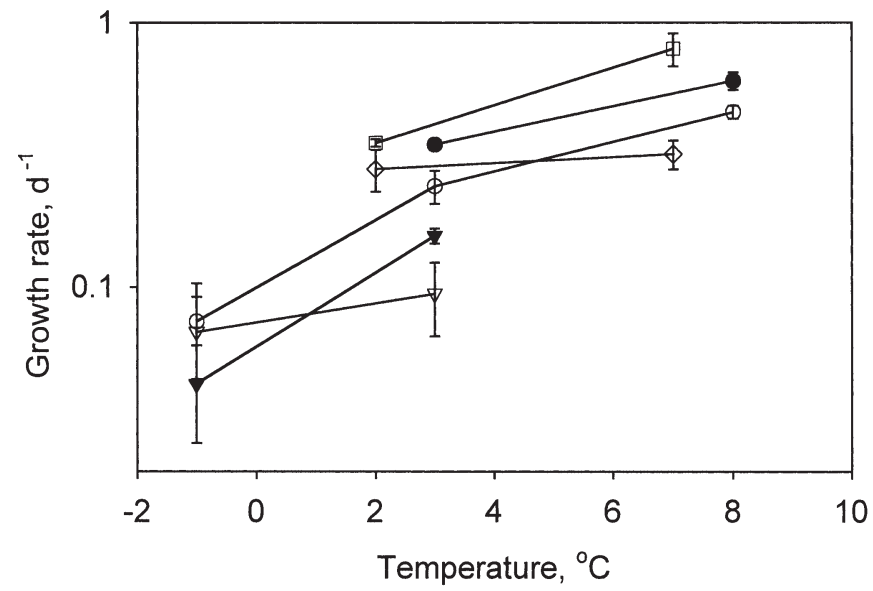

Fig. 6. Summary of the relation between bacterial growth rate and temperature in the experiments where temperature was manipulated. $\diamond$ : Expt 1 Ctrl $(12 \mu \mathrm{M} \mathrm{C})_{i}-\square-$ : Expt 2 Ctrl $(22 \mu \mathrm{M} \mathrm{C}) ;-0-$ : Expt $3 \mathrm{Ctrl}(10 \mu \mathrm{M} \mathrm{C}) ;-\longrightarrow$ - Expt $3+\mathrm{C}(40 \mu \mathrm{M}$ $\mathrm{C})_{i} \rightarrow \nabla$ : Expt $4 \mathrm{Ctrl}(0.8 \mu \mathrm{M} \mathrm{C})_{i} \rightarrow \boldsymbol{\nabla}$ : Expt $4+\mathrm{C}(31 \mu \mathrm{M}$ C). The carbon concentration indicates approximate DOC-L concentration estimated from DOC uptake during the experiments

cant $(\mathrm{p}<0.0001)$. The log-transformation of $\mu$ and DOC-L, but not temperature, is based on assuming an exponential relationship between temperature and growth rate. Using a log-transformation of all variables in the model explained $79 \%$ of the variation and again both the overall model and the individual factors were significant (Table 3). The temperature effect on growth rate could thus be modelled as a linear or an exponential effect with almost the same $r^{2}$ and significance. Determination of a $Q_{10}$ value from the parameter estimate of an linear regression model of $\log (\mu)$ versus temperature (and DOC-L) gave a value near 6 (SE range: 5 to 8 ). However, using only data with temperatures of 2 to $8^{\circ} \mathrm{C}$ resulted in a $Q_{10}$ of 3.0 (2.4 to 3.8 ) while in the range of -1 to $3^{\circ} \mathrm{C}$ the $Q_{10}$ was much higher, indicating an increased effect of temperature in the low temperature range.

\section{DOC lability}

Bacterial biomass and DOC-L uptake was calculated from cell abundances using a cell carbon content of $1.9 \mathrm{fmol} \mathrm{C}$ cell $^{-1}$ (estimated in DOC-L incubations with surface water samples) and a growth efficiency of 0.26 (determined in the growth experiments with surface water samples without glucose addition). Bacterial growth on DOC in the lability experiments with surface water from the Greenland Sea was generally characterized by 2 growth phases, as exemplified in Fig. 7. The DOC-L experiments were performed for $7 \mathrm{~d}$ at $20^{\circ} \mathrm{C}$ and generally the bacterial biomass increased exponentially during the first 2 to $4 \mathrm{~d}$ with growth rates 
Table 3. General linear models describing the effect of temperature, $T\left({ }^{\circ} \mathrm{C}\right)$, and concentration of DOC-L $(\mu \mathrm{M})$ on growth rate $\left(\mathrm{d}^{-1}\right)$. P:B is the in situ growth rate and $\mu$ is the growth rate determined in batch cultures. DOC-L concentrations have been estimated from the total DOC uptake in the control incubations plus the optional glucose addition. In Model 2 all variables have been log-transformed, while only growth rate and DOC-L concentration are log-transformed in Models 1, 3, 4 and 5. Parameter estimates are indicated with $\pm 1 \mathrm{SE}$ and significance level. $Q_{10}$ values are calculated from the temperature coefficient, $\mathrm{A}$, in Models $1,3,4$, and 5 according to $Q_{10}=10^{(\mathrm{A} \times 10)}$. Analysis has been conducted using SAS software (SAS Institute)

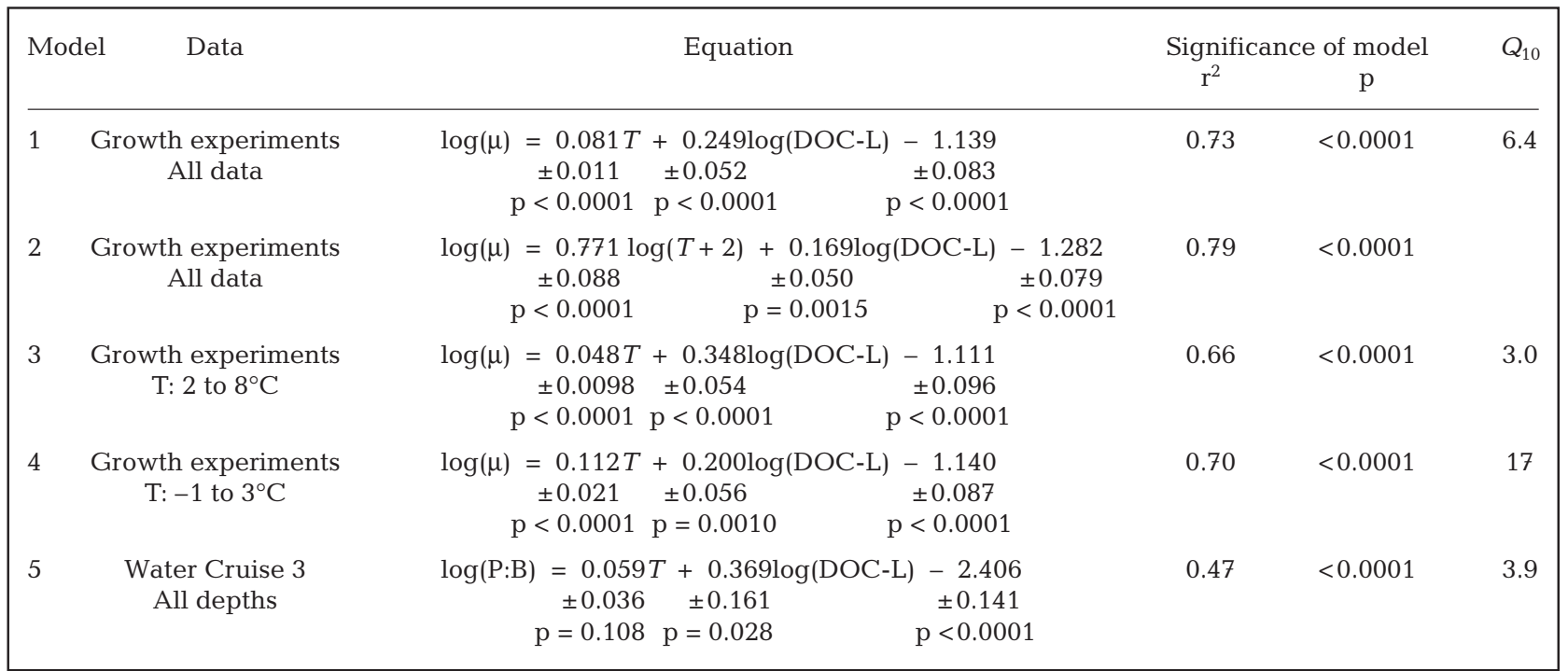

ranging from 0.12 to $0.73 \mathrm{~d}^{-1}$ in surface water incubations. The concentration of DOC-L was estimated as the amount of carbon utilized by the bacteria within the $7 \mathrm{~d}$ incubations. In lability experiments from deepwater samples, a lag phase prior to bacterial growth was usually observed (Fig. 7) and the rate of biomass increase was generally lower than in surface water incubations (0.08 to $0.18 \mathrm{~d}^{-1}$ ).

DOC-L concentration ranged from $13.5 \mu \mathrm{M}$ C $(5 \mathrm{~m}$ depth) to $<0.1 \mu \mathrm{M} \mathrm{C}$ in some of the deep-water

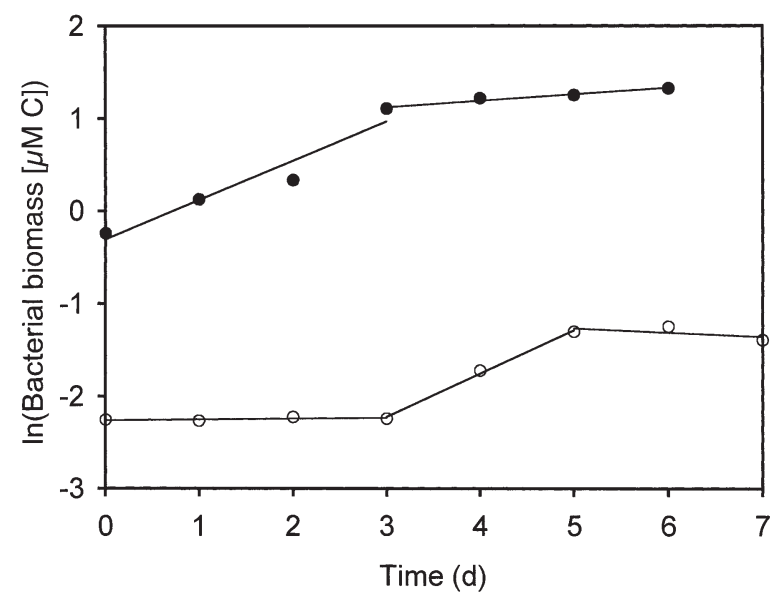

Fig. 7. Example from a surface water sample $(\bullet)$ and a deep water sample (0) of the development in bacterial biomass during the $7 \mathrm{~d}$ experiments used to measure DOC-L concentrations samples and showed a significant decrease with depth (Fig. 8, log-log transformed data, $\mathrm{r}^{2}=0.78, \mathrm{p}<0.0001$ ). The average DOC-L concentration in samples from $>100 \mathrm{~m}$ depth was $3.8 \pm 3.4 \mu \mathrm{M} \mathrm{C}( \pm \mathrm{SE}, \mathrm{n}=29)$, $<1000 \mathrm{~m}$ it was $0.28 \pm 0.21 \mu \mathrm{M} \mathrm{C}(\mathrm{n}=12)$. There were no obvious patterns in the horizontal distribution of DOC-L concentration in the investigated area of the Greenland Sea, either in relation to the water masses (Polar, Arctic and Atlantic salinity/temperature characteristics) or in the distance from the retracting ice edge.

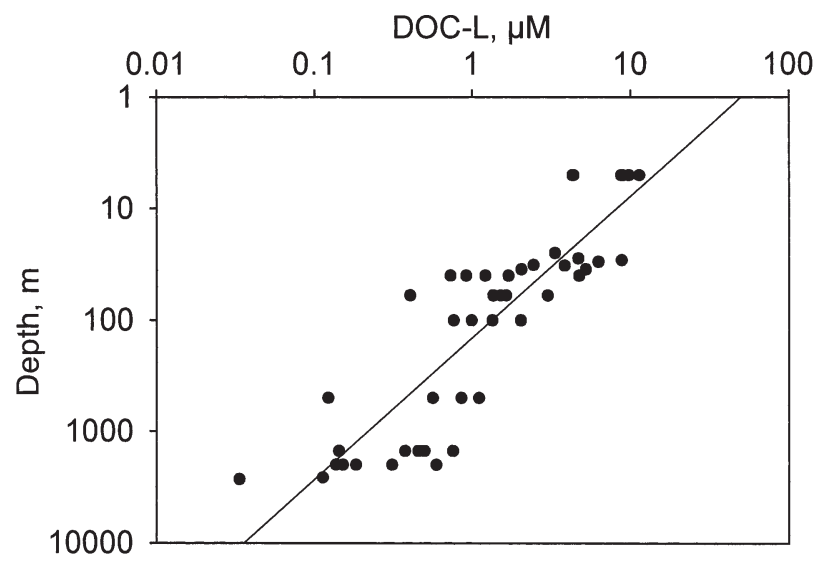

Fig. 8. Distribution of DOC-L concentration with depth in the Greenland Sea during August 1999. Regression line represents linear regression of the $\log (\mathrm{DOC}-\mathrm{L})$ versus $\log$ (Depth) with the equation: $\log (\mathrm{DOC}-\mathrm{L})=-0.613( \pm 0.050) \times \log ($ Depth $)$ $+2.42( \pm 0.11), \mathrm{r}^{2}=0.78, \mathrm{p}<0.0001$ 


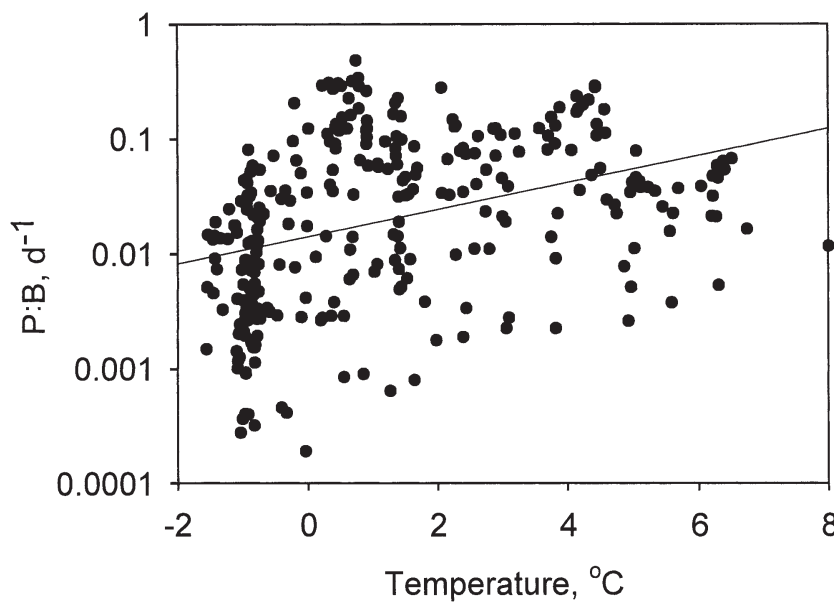

Fig. 9. Relationship between bacterial growth rate (P:B) and temperature in the Greenland Sea during June and August 1999, using all available data. Regression line represents linear regression of $\log (\mathrm{P}: \mathrm{B})$ versus temperature with the equation: $\log (\mathrm{P}: \mathrm{B})=0.118 \times$ temperature $-1.84, \mathrm{r}^{2}=0.14, \mathrm{p}<0.0001$

\section{In situ growth rate}

The in situ bacterial growth rate (P:B) as estimated from simultaneous measurements of bacterial production and biomass ranged from 0.0002 to $0.5 \mathrm{~d}^{-1}$ (Fig. 9). For the subset of data which contained data for both bacterial growth rate and concentration of DOC-L, the growth rate was correlated positively with both DOC-L and temperature (Fig. 10, open circles). As for the growth experiments, we analyzed the combined effect of DOC$\mathrm{L}$ and temperature on in situ bacterial growth rate using multiple linear regression and ANOVA (Table 3). For the August dataset, $47 \%$ of the observed variation in $\log (\mathrm{P}: \mathrm{B})$ could be explained by a linear model with following parameter estimates: $\log (\mathrm{P}: \mathrm{B})=0.37 \times$ $\log ($ DOC-L $)+0.059 \times$ temperature -2.41 . The overall model was significant $(\mathrm{p}<0.0001)$ and showed a positive contribution from both DOC-L concentration and temperature on growth rate; however, only the effect of DOC-L was significant $(p<0.05)$ (Table 3$)$. The significance of the temperature effect was not improved if temperature data were also log-transformed. Generally, the parameter estimates and the actual ranges of $\log (\mathrm{DOC}-\mathrm{L})$ and temperature indicated a slightly larger contribution from DOC-L than from temperature to the range of predicted growth rates. Growth rates obtained from culture experiments were higher than the $\mathrm{P}: \mathrm{B}$ ratios determined on the same water samples; however, the temperature and DOC-L effects from the 2 data sets showed the same pattern (Fig. 10). Accordingly, the parameter estimates of temperature and DOC-L coefficients were not significantly different in the 2 models of experimental and in situ data, respectively (Table 3, Models 1 and 5); only the intercepts differed.

\section{DISCUSSION}

\section{Regulation of bacterial DOC uptake in growth experiments}

The temperature-substrate dependent growth responses of bacterial carbon uptake and growth rate that were observed in bacterial growth experiments indicated that bacterial activity in the Greenland Sea was regulated by a combination of temperature and substrate concentration (Table 2, Figs. 4, 5, 6 \& 10). Increasing temperature relative to in situ conditions always increased growth rate and the opposite effect was obtained by decreasing temperature. In all experiments with surface water, glucose enrichment increased growth rate significantly. The effect of glucose and temperature was not significant in the deepwater sample, where the growth rates were low and therefore subject to high relative variance when determined as in the growth experiments.

Temperature influences all biological reaction rates, including the rates of processes limited by substrate availability, however, the substrate and temperature interactions may be complex and are under debate (e.g. Rivkin et al. 1996, Pomeroy \& Wiebe 2001). Increasing temperature generally results in increased bacterial activity until the optimum temperature for the given bacterial population is reached. However, a number of culture experiments with bacterial isolates have shown that at temperatures approaching the lower limit for bacterial growth, the relation between growth rate and temperature deviates from the general exponential relationship and declines dramatically

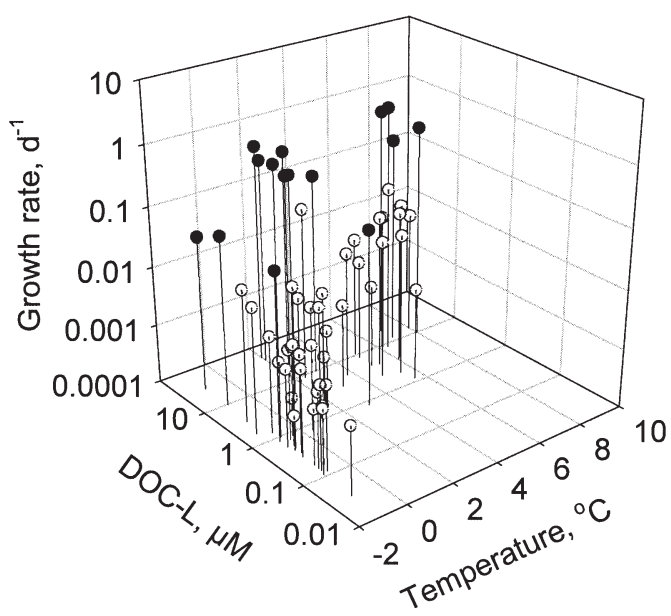

Fig. 10. Relationship between growth rate, temperature and DOC-L concentration. (O) In situ P:B data; $(\bullet) \mu$ data from the growth experiments. DOC-L concentrations in growth experiments were estimated from the DOC uptake in the control incubations, plus the optional glucose addition 
(Pomeroy \& Wiebe 2001). Accordingly, our data from the growth experiments showed higher $Q_{10}$ values calculated for the range -1 to $3^{\circ} \mathrm{C}$ than the mean value of 3.0 obtained in the range from 2 to $8^{\circ} \mathrm{C}$ (Table 3, Fig. 6). Particularly the surface bacteria originating from a $3^{\circ} \mathrm{C}$ water mass showed a pronounced reduction in growth rate with decreasing temperature.

The negative effects of low temperature on bacterial growth rate may be associated with a reduced substrate assimilation efficiency (Morita \& Buck 1974, Nedwell 1999) or reduced substrate diffusion rates (Jumars et al. 1993) at very low temperatures. It has been suggested that the high relative decrease in growth rate at low temperatures may be more pronounced at low substrate concentrations than at high (Pomeroy et al. 1991, Wiebe et al. 1992, 1993, Pomeroy \& Wiebe 2001). Our results on temperature-substrate interactions support the idea that there may be an increased effect of temperature at sub-zero temperatures, but the data do not allow discrimination between the effect on half saturation constants and on maximum uptake rates.

The additional bacterial carbon uptake in the glucose-enriched cultures relative to the control cultures could account for 20 to $80 \%$ of the added glucose in Expts 1 to 3 . Thus, the bacterial growth rates in the cultures ( 0.31 to $0.35 \mathrm{~d}^{-1}$ ) were too slow to allow a complete utilization of both the natural DOC-L and the added glucose during the $11 \mathrm{~d}$ of incubation. In general, however, bacterial DOC uptake and growth rate in the batch culture experiments with surface water was significantly stimulated $(\mathrm{p}<0.05)$ by enrichment with DOC-L (Figs. 4 \& 5, Table 2).

Addition of inorganic nutrients had no significant influence on bacterial carbon uptake, and it can be concluded that bacterial carbon turnover was not limited by inorganic nutrients in the Greenland Sea at the period of this investigation. Theoretically, the natural pools of nitrate and phosphate (Table 1) may be sufficient to support the utilization of the natural and added DOC-L pools (assuming Redfield ratio and a growth efficiency of 0.26 ) in all experiments except Expt 3 $(<0.1 \mu \mathrm{M}$ inorganic $\mathrm{N})$. Addition of $\mathrm{NH}_{4}{ }^{+}$in this experiment did not stimulate growth, indicating that bacterial utilization of natural DOC-L was not limited by inorganic nitrogen. The relatively small increase in bacterial carbon uptake in the glucose-enriched cultures (Expt 3, Table 2), suggested, however, that glucose uptake was limited by nitrogen availability in that experiment.

\section{Concentration and turnover of DOC-L}

The concentration of DOC-L in the upper $30 \mathrm{~m}$ and in the deep waters $(>1000 \mathrm{~m})$ ranged from 3.1 to
13.5 and 0.03 to $0.70 \mu \mathrm{M} \mathrm{C}$, respectively. This corresponded well with the observed carbon uptake during the $11 \mathrm{~d}$ incubations at in situ temperature as well as at increased temperature in the growth experiments, though the uptake in Expt 2 exceeded the general range of DOC-L estimates. However, water for Expt 2 was from the ice edge on the July cruise, where parallel DOC-L measurements were not taken. Generally, the uptake in growth experiments were in the upper range of the DOC-L values and this may also indicate that the extra handling in various types of containers as well as the filtration using capsules may have added traces of DOC-L to the water incubated in the growth experiments. Nevertheless, the consistent levels of DOC-L found in the 2 types of experiments indicate that the measured pool of DOC-L constituted a significant substrate pool and that the quantification of DOC$\mathrm{L}$ was not sensitive to the protocol for determination. The obtained surface water concentrations of DOC-L were in the low end of, or even lower than, the range of previous obtained DOC-L values from predominantly coastal marine surface waters (8 to $200 \mu \mathrm{M}$ C) (Søndergaard \& Middelboe 1995). The low DOC-L level accords with the low concentrations of total DOC (50 to $70 \mu \mathrm{M} \mathrm{C}$, Lundsgaard et al. unpubl. data) in the Greenland Sea surface water, relative to concentrations in coastal environments.

There is a potential risk of organic contamination in the DOC-L experiments due to water filtration and handling of incubation bottles. The fact that we found indications for a thriving microbial food web in the deep sea (i.e. significant bacterial production and significant abundance of both viruses and heterotrophic flagellates (Lundsgaard et al. unpubl. data) supported the observed presence of a pool of DOC-L in the deep sea. Any systematic DOC contamination due to filtration etc. would influence the absolute DOC-L values, but not the observed gradient with depth (Fig. 8). If systematic contamination occurred, the concentration introduced this way would possibly be lower than the DOC-L concentrations measured in the deepest samples $(2700 \mathrm{~m})$. Even if DOC-L in the deepest samples are assumed to equal the contamination level and are subtracted all the other values, the data still show a significant DOC-L concentration as deep as $2000 \mathrm{~m}$. Though we cannot exclude that the absolute DOC-L value measured in the deep sea may be slightly overestimated due to contamination, such a small overestimation would not change the general conclusions.

DOC-L was defined here as the total amount of carbon consumed during $7 \mathrm{~d}$ incubation. Results from the lability experiments and growth experiments with surface water showed that bacterial growth on DOC-L was generally characterized by 2 different phases (Fig. 7), thus the DOC-L was composed of a fraction 
supporting rapid bacterial growth, and a fraction supporting significantly lower bacterial growth rates. The slowly degrading fraction was probably not depleted during the incubations (Fig. 7). This second pool of DOC-L may be defined as semi-labile, since it was utilized at a much lower rate than the first pool. DOC-L is, therefore, not an estimate of the total pool of biodegradable DOC, but provides an estimate of the fraction of the biodegradable DOC that is readily utilized by bacteria.

The observation of a small pool of DOC-L in the deep samples was interesting, since this is the most significant direct indication of such DOC-L in the deep ocean. In deep ocean samples (>1200 m depth) from the western Atlantic, Barber (1968) could not detect any DOC-L as measured by persulfate wet oxidation, and he suggested that deep-sea DOC is relatively resistant to biochemical oxidation. Similarly, previous estimates of an average ${ }^{14} \mathrm{C}$ age of DOC from the deep Pacific of about 6000 yr (Williams \& Druffel 1987), suggested that deep-sea DOC is biochemically inert. Kähler et al. (1997) found very limited bacterial growth in experiments using water from $1000 \mathrm{~m}$ depth in the Southern Ocean. However, they did not expect DOC-L to be present at this depth and attributed the growth to DOC contamination of the samples. Indeed, total DOC concentrations measured in that study were among the lowest measured in marine environments. The presence of a small concentration of DOC-L in the Greenland Sea deep waters $(>1000 \mathrm{~m})$ is, however, not surprising given the fact that a substrate input is needed to support bacterioplankton production of $<0.1$ to $5 \mathrm{nM} \mathrm{C} \mathrm{d}^{-1}$ (average \pm SE: $1.3 \pm 0.2 \mathrm{nM} \mathrm{C} \mathrm{d}^{-1}, \mathrm{n}=57$ ) based on ${ }^{14} \mathrm{C}$-leucine incorporation (Lundsgaard et al. unpubl. data). The turnover time for DOC-L in the deep sea was, thus, $56 \mathrm{~d}$ based on mean DOC-L concentration and mean bacterial production at depth $>1000 \mathrm{~m}$ applying a growth efficiency of 0.26 (range: 26 to $943 \mathrm{~d}$ when calculated on data pairs from separate water samples). Barber (1968) also detected viable bacteria in the deep-sea samples, which suggested a supply of substrate. The reason he did not measure any DOC-L may have been that the detection limit of the persulfate oxidation method ( 8 $\mu \mathrm{M}$ C) (Barber 1968) was far above the highest concentrations of deep-sea DOC-L that was measured in the present study.

The presence of DOC-L in the deep sea supports previous suggestions that bacterial biomass and production in the deep sea is coupled with sinking POC fluxes (Cho \& Azam 1988, Nagata et al. 2000). Diffusive transport of DOC-L from the euphotic zone to depths $<1000 \mathrm{~m}$ is too slow to explain the existence of DOC-L with fast turnover rates at that depth (Bendtsen et al. 2002). The deep convective mixing- another potential transport mechanism in the areatakes place during winter, and the deep DOC-L from August should then have been produced the previous year in order to have been transported by this mechanism. Convective mixing is, however, not a likely explanation of the observed deep-water DOC-L concentrations. The observed mean DOC-L concentration of $3.8 \mu \mathrm{M}$ in the upper $100 \mathrm{~m}$ is not high enough to yield deep-sea DOC-L values of $0.28 \mu \mathrm{M}$ if mixed with DOC-L poor water to depths of $>2000 \mathrm{~m}$. Moreover, winter DOC-L concentrations are not likely to be higher than the August values, since there are no significant primary production in the dark winter months, while DOC-L consumption is expected to continue as long as this substrate is present. Sedimentation, on the other hand, has the potential for fast transport of organic particles from the productive layer to the deep sea, where DOC may be released by dissolution of the sedimenting particles (Bendtsen et al. 2002).

\section{Regulation of bacterial growth in the Greenland Sea}

We used the field data for bacterial growth rate (bacterial production divided by biomass), temperature and DOC-L to investigate the importance of temperature and substrate concentration in the regulation of in situ bacterial growth rate. The results from the field data were in accordance with the observed influence of temperature and substrate on bacterial growth rate in the manipulated growth experiments (Table 3 , Fig. 10). The significant influence of in situ DOC-L concentration on bacterial growth rate $(p<0.05)$ as described in the model (Table 3) was, thus, a strong indication that substrate concentration was a major regulating factor for bacterial growth in the Greenland Sea. The overall model was highly significant $(p<$ 0.0001 ) and was able to explain almost half of the variability in in situ bacterial growth rate in the Greenland Sea and the major part of the variability in the controlled growth experiments (Table 3). Although in situ DOC-L and temperature were also positively correlated, we assume that this was due to the overall decrease in DOC-L and temperature with depth and was not the result of a causal relationship between DOC-L and temperature. Consequently, we infer that the observed relationships between bacterial growth rate and both DOC-L and temperature were causal relationships.

The large range in growth rates (almost 4 orders of magnitude) measured at sub-zero temperatures (Fig. 9) indicated that temperature was not a strong regulator of bacterial growth rate, when considering data from all water masses and depths in the Green- 
land Sea. The water temperature did not correlate with depth in the upper $100 \mathrm{~m}$, but rather the temperature distribution was determined by the horizontal distribution of water masses in the Greenland Sea (not shown). Consequently, temperatures in the upper $100 \mathrm{~m}$ covered the whole range from -1.5 to $8^{\circ} \mathrm{C}$ and at some stations, sub-zero temperatures were found from the surface to the deep sea, thus covering a wide range of DOC-L concentrations. Consequently, different bacterial assemblages growing at sub-zero temperatures in the Greenland Sea experienced highly variable substrate concentrations, which may explain part of the scatter when compiling all the simultaneous measurements of in situ bacterial growth rate and water temperature (Fig. 9).

In a study in the equatorial Pacific, Kirchman et al. (1995) found a significant temperature effect on bacterial growth rate in culture experiments, whereas the in situ bacterial growth rate in surface water correlated with primary production and not temperature. They concluded that supply of substrate associated with primary production was the main regulating factor for bacterial production under in situ conditions, and that temperature was of secondary importance for understanding the role of bacteria in equatorial Pacific. In a later study, Kirchman \& Rich (1997) argued that even though substrate was the main limiting factor for bacterial growth, temperature may modulate the controlling effects of substrate by affecting the response time and affinity of bacteria for the limiting substrate. In a compilation of 66 studies on in situ measurements of bacterial growth rate, which covered a temperature range from -2 to $30^{\circ} \mathrm{C}$, Rivkin et al. (1996) found a weak but significant positive correlation between temperature and growth rate. From this, Rivkin et al. (1996) suggested that temperature was not the principal factor controlling bacterial processing of organic carbon in the global ocean.

In the present study, the results obtained from the bacterial growth experiments could be applied directly to the conclusions drawn from the in situ correlations between growth rate and DOC-L and temperature, respectively (Figs. $6 \& 10$ ). We suggest, therefore, that the interacting effects of temperature and substrate were important regulators of bacterial growth in the Greenland Sea.

Acknowledgements. The study was supported by the Danish Natural Sciences Research Council (Grant \#97001196), and the Carlsberg Foundation (Grant \#990689/20-1307). We thank Marina Madsen and Lene Hemmingsen for excellent technical assistance and the captain and crew on RV 'Dana' for support during the cruises. Niels Henrik Borch is acknowledged for help with determination of bacterial numbers by flow cytometry.

\section{LITERATURE CITED}

Barber RT (1968) Dissolved organic carbon from deep waters resists microbial oxidation Nature 220:274-275

Bendtsen J, Lundsgaard C, Middelboe M, Archer D (2002) Influence of bacterial uptake on deep-ocean dissolved organic carbon. Global Biogeochem Cycl 16(4):1127

Børsheim KY (2000) Bacterial production rates and concentrations of organic carbon at the end of the growing season in the Greenland Sea. Aquat Microb Ecol 21:115-123

Børsheim KY, Myklestad SM (1997) Dynamics of DOC in the Norwegian Sea inferred from monthly profiles collected during 3 years at $66^{\circ} \mathrm{N}, 2^{\circ}$ E. Deep-Sea Res I 44:593-601

Buch E, Nielsen TG, Lundsgaard C, Bendtsen J (2001) Deep water convection and biogeochemical cycling of carbon in the North Atlantic. In: Jørgensen AMK, Fenger J, Halsnæs $\mathrm{K}$ (eds) Climate change research-Danish contributions. Danish Meterological Institute/Danish Climate Centre, Copenhagen, p 53-76

Chin-Leo G, Kirchman DL (1988) Estimating bacterial production in marine waters from simultaneous incorporation of thymidine and leucine. Appl Environ Microbiol 54: 1934-1939

Cho BC, Azam F (1988) Major role of bacteria in biogeochemical fluxes in the ocean's interior. Nature 332:441-443

Grasshoff K, Ehrhardt M, Kremling K (eds) (1983) Methods of seawater analysis, 2nd edn. Verlag-Chemie, Weinheim

Jumars PA, Deming JW, Hill PS, Karp-Boss L, Yager PL, Dade WB (1993) Physical constraints on marine osmotrophy in an optimal foraging context. Mar Microb Food Webs 7 : 121-159

Kähler P, Bjørnsen PK, Lochte K, Antia A (1997) Dissolved organic matter and its utilization by bacteria during spring in the Southern Ocean. Deep-Sea Res II 44:341-353

Kirchman DL, Rich JH (1997) Regulation of bacterial growth rates by dissolved organic carbon and temperature in the equatorial Pacific Ocean. Microb Ecol 33:11-20

Kirchman DL, Rich JH, Barber RT (1995) Biomass and biomass production of heterotrophic bacteria along $140^{\circ} \mathrm{W}$ in the equatorial Pacific: effect of temperature on the microbial loop. Deep-Sea Res II 42:603-619

Marie D, Partensky F, Jacquet S, Vaulot D (1997) Enumeration and cell cycle analysis of natural populations of marine picoplankton by flow cytometry using the nucleic acid stain SYBR Green 1. Appl Environ Microbiol 63: 186-193

Middelboe M, Nielsen TG, Bjørnsen PK (2002) Viral and bacterial production in the North Water polynya: in situ measurements, batch culture experiments and characterization and distribution of a virus-host system. Deep Sea Res 49:5063-5079

Morita RY, Buck GE (1974) Low temperature inhibition of substrate uptake. In: Colwell RR, Morita RY (eds) Effect of the ocean environment on microbial activities. University Park Press, Baltimore, p 124-129

Nagata T, Fukuda H, Fukuda R, Koike I (2000) Bacterioplankton distribution and production in deep Pacific waters: large-scale geographic variations and possible coupling with sinking particle fluxes. Limnol Oceanogr 45:426-435

Nedwell DB (1999) Effect of temperature on microbial growth: lowered affinity for substrates limits growth at low temperatures. FEMS Microbiol Ecol 30:101-111

Noji T, Rey F, Miller LA, Børsheim KY, Urban-Rich J (1999) Fate of biogenic carbon in the upper $200 \mathrm{~m}$ of the central Greenland Sea. Deep-Sea Res II 46:1497-1509

Pomeroy LR, Wiebe WJ (2001) Temperature and substrates as interactive limiting factors for marine heterotrophic bacte- 
ria. Aquat Microb Ecol 23:187-204

Pomeroy LR, Wiebe WJ, Deibel D, Thompson RJ, Rowe GT, Pakulski JD (1991) Bacterial responses to temperature and substrate concentration during the Newfoundland spring bloom. Mar Ecol Prog Ser 75:143-159

Porter KG, Feig YS (1980) The use of DAPI for identifying and counting aquatic microflora. Limnol Oceanogr 25:943-948

Rivkin RB, Anderson MR, Lajzerowicz C (1996) Microbial processes in the cold oceans. I. Relationship between temperature and bacterial growth rate. Aquat Microb Ecol 10: 243-254

Rudels B, Quadfasel D (1991) Convection and deep water formation in the Arctic Ocean- Greenland Sea system. J Mar Systems 2:435-450

Smith DC, Simon M, Alldredge AL, Azam F (1992) Intense hydrolytic enzyme activity on marine aggregates and implications for rapid particle dissolution. Nature 359: 139-142

Søndergaard M, Middelboe M (1993) Particulate organic carbon: a note on the use of glass fiber (GF/F) and anodisc filters. Arch Hydrobiol 127 (1):73-85

Søndergaard M, Middelboe M (1995) A cross-system analysis

Editorial responsibility: Gerhard Herndl,

Den Burg, The Netherlands of labile dissolved organic carbon. Mar Ecol Prog Ser 118: 283-294

Thingstad TF, Hagström $\AA$, Rassoulzadegan F (1997) Accumulation of degradable DOC in surface waters: is it caused by a malfunctioning microbial loop. Limnol Oceanogr 42:398-404

Thingstad TF, Zweifel UL, Rassoulzadegan F (1998) P limitation of heterotrophic bacteria and phytoplankton in the northwest Mediterranean. Limnol Oceanogr 43:88-94

Wheeler PA, Gosselin M, Sherr E, Thibault D, Kirchman DL, Benner R, Whitledge TE (1996) Active cycling of organic carbon in the central Arctic Ocean. Nature 380:697-699

Wiebe WJ, Sheldon WM, Pomeroy LR (1992) Bacterial growth in the cold: evidence for enhanced substrate requirement. Appl Environ Microbiol 58:359-364

Wiebe WJ, Sheldon WM, Pomeroy LR (1993) Evidence for an enhanced substrate requirement by marine mesophilic bacterial isolates at minimum growth temperatures. Microb Ecol 25:151-159

Williams PM, Druffel ERM (1987) Radiocarbon in dissolved organic carbon in the central north Pacific Ocean. Nature 330:246-248

Submitted: November 8, 2002; Accepted: February 14, 2003 Proofs received from author(s): May 19, 2003 